\title{
PRINSIP-PRINSIP HUKUM TERKAIT PERLINDUNGAN NAMA ORANG TERKENAL SEBAGAI NAMA DOMAIN DI INDONESIA
}

\author{
Muhamad Amirulloh \\ Fakultas Hukum Universitas Padjadjaran \\ E-mail: muammar_2@yahoo.com
}

\begin{abstract}
ABSTRAK. Prinsip-prinsip hukum yang terkait dengan penggunaan nama orang terkenal sebagai nama domain (cybersquatting) perlu dilakukan sebagai acuan dasar penyusunan konsep perlindungan bagi orang terkenal tersebut dalam rezim hukum merek di Indonesia serta Undang-undang Nomor 11 Tahun 2008 tentang Informasi dan Transaksi Elektronik. Nama orang terkenal dalam perkembangan Teknologi Informasi dan Komunikasi mengalami perubahan pendekatan dalam perlindungannya. Pada awalnya nama orang terkenal adalah hak pribadi telah menjelma menjadi hak kebendaan dalam praktik nama domain. Beberapa prinsip hukum merek juga dikaji relevansinya dengan praktik cybersquatting terhadap nama orang terkenal mengingat keduanya bersumber dari adanya reputasi yang harus dilindungi oleh hukum. Metode pendekatan yang digunakan dalam penelitian ini adalah yuridis normatif, dengan spesifikasi penelitian deskriptif analitis. Hasil penelitian memperlihatkan bahwa, prinsip nemo plus, droit de suit, itikad baik, prinsip persamaan, dan prinsip penggunaan dalam kegiatan perdagangan atau bisnis dapat digunakan dalam melindungi orang terkenal dari penggunaan namanya sebagai nama domain.Konsep pengaturan merek yang lebih memadai dalam melindungi orang terkenal dari penggunaan namanya sebagai nama domain adalah konsep pengaturan yang mengandung hal-hal sebagai berikut, pertama, penetapkan ruang lingkup hak ekslusif merek adalah juga mencakup pendaftaran dan penggunaan nama orang terkenal sebagai nama domain di internet. Kedua, pelarangan penggunaan nama orang terkenal sebagai nama domain oleh pihak lain secara tanpa hak dan dengan itikad buruk. Ketiga, pemberian hak kepada orang terkenal untuk mengajukan gugatan ganti rugi perdata terhadap cybersquatter.Keempat, pemberian kewenangan kepada pengadilan niaga untuk memeriksa dan mengadili perkara cybersquattingterhadap orang terkenal.
\end{abstract}

Kata kunci: nama orang terkenal, nama domain, nemo plus, droit de suit, itikad baik.

\section{PRINCIPLES LEGAL RELATED PERSON 'S NAME PROTECTION BRANDS DOMAIN NAMES IN INDONESIA}

\begin{abstract}
The Legal principles relating to the use of a famous person's name as a domain name (cybersquatting) needs to be done as a basic reference for the formulation of the concept of the protection of such famous name in the trademark regime in Indonesia as well as Law No. 11 of 2008 on Information and Electronic Transactions. Name of famous person in the development of Information and Communication Technology changes in the approach to protection. At first name of a famous person is a personal right has been transformed into the right material in the practice of domain name. Some brands also reviewed the legal principles relevant to the practice of cybersquatting to remember the names of famous people are both derived from the reputation should be protected by law. The concept of trademark law that is more adequate in protecting the famous person's name as a domain name is a draft regulation containing matters as follows, first, the scope of exclusive rights is also includes the registration and the use of the name of a famous person as domain names on the Internet. Secondly, the prohibition of the use of a famous person's name as a domain name by another party unlawfully and in bad faith. Thirdly, granting the right to a famous person to file a civil claim for damages against a cybersquatter. Fourth, giving authority to the commercial court to examine and adjudicate cybersquatting case against a famous person.
\end{abstract}

Key words: Famous person's name, domain name, nemo plus, droit de suit, good faith.

\section{PENDAHULUAN}

Nama orang terkenal mengandung makna tertentu tentang reputasi pribadi orang terkenal tersebut. Nama orang terkenal juga memiliki daya tarik yang kuat dan besar bagi pihak lain atau masyarakat terhadap informasi yang berkaitan dengan orang terkenal tersebut. Dalam hukum merek, orang terkenal juga mendapatkan perlindungan dari penggunaan dan/atau pendaftaran namanya sebagai merek yang dilakukan pihak lain secara tanpa ijin orang terkenal tersebut.

Dalam internet, salah satu bentuk penggunaan nama orang terkenal adalah sebagai nama domain. Penggunaan nama domain sebagai sarana perdagangan secara elektronik (electronic commerce) menjadi salah satu strategi bisnis era millenium yang paling jitu mengingat kemampuannya dalam promosi dan distribusi produk dapat menjangkau ke seluruh pelosok dunia dalam waktu yang sangat singkat. Pelanggaran kepemilikan nama domain akan mengakibatkan kerugian yang serius dalam aktivitas bisnis.

Penggunaan nama domain menjadi strategi bisnis yang ampuh bagi pelaku usaha untuk meningkatkan pendapatan dan mengembangkan bisnisnya, karena aktivitas bisnis dan perdagangan dapat dilakukan 24 jam sehari dan 7 hari seminggu, serta dapat dilakukan diseluruh belahan dunia tanpa ada halangan jarak, ruang dan waktu. ${ }^{1}$

Berdasarkan data dari Pengelola Nama Domain Internet Indonesia (PANDI), jumlah nama domain

\footnotetext{
${ }^{1 .}$ Bdgk. David Baumer, J.C. Poindexter, Cyberlaw and E-Commerce: Security, Risk Management, and Control, New York: McGrawHill, 2002, hlm. 297. Lihat pula: Aamna, "Cybersquatting: Indian and American Law", http://jurisonline.in/?p=2644, 21 okt 2011, didownload tanggal 18 Februari 2012, Pukul 06.00 wib.
} 
yang terdaftar di Indonesia per September 2015adalah sebanyak 148.376nama domain. Jumlah itu meningkat kurang lebih sebanyak 20\% dari data bulan Januari 2015 yang hanya sebanyak 123.960 buah, sebagaimana dapat digambarkan dalam Tabel 1.

Tabel 1. Nama Domain yang terdaftar di Indonesia 2015
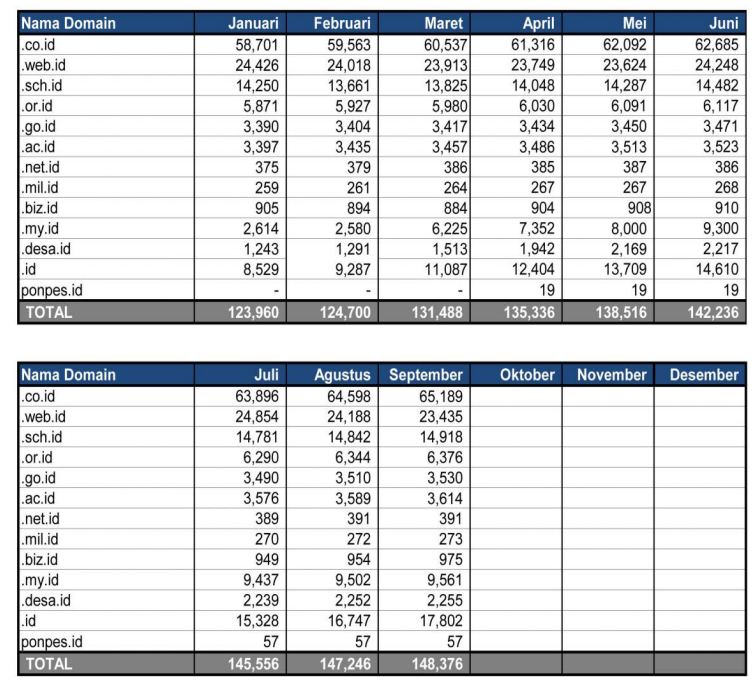

Jumlah pengguna nama domain lokal diprediksi akan meningkat sebanyak $10 \%$ setiap tahunnya. ${ }^{2}$ Perkembangan ini berpotensi diikuti dengan perkembangan sengketa kepemilikan nama domain di Indonesia, termasuk penggunaan nama orang terkenal sebagai nama domain.

Kasus penggunaan nama orang terkenal sebagai nama domain sudah banyak terjadi, misalnya kasus juliaroberts.com dan tomcruise.com.Hal ini menimbulkan kerugian ekonomi bagi orang terkenal karena menjadi tidak dapat menggunakan namanya sebagai nama domain dalam melakukan aktivitas di dunia maya (cyberspace), apalagijikabisnisnyajuga dijalankanmelaluie-commerce. hilangnya pendapatan yang seharusnya diperoleh, potensi keuntungan, bahkan rusaknya reputasi. Dengan kata lain, orang terkenal tersebut menjadi kehilangan hak eksklusif dan kesempatan dalam berbisnis di internet, padahal internet dengan e-commerce juga dapat menjadi tempat untuk melakukan kegiatan perdagangan barang dan / atau jasa.

Pasal 23 ayat (2) UU ITE telah dengan tegas menyatakan bahwa, "Pemilikan dan penggunaan nama domain sebagaimana dimaksud pada ayat (1) harus didasarkan pada iktikad baik, tidak melanggar prinsip persaingan usaha secara sehat, dan tidak melanggar hak orang lain." Dalam penjelasannya, dinyatakan bahwa menggunakan nama orang terkenal juga termasuk "melanggar hak orang lain". Ketentuan ini memberikan efek domino khususnya bagi UU Merek yang juga mengatur penggunaan nama orang terkenal dalam kegiatan perdagangan atau bisnis. UU Merek harus diharmonisasikan dengan UU ITE.

2.http://www.300ribu.com/domain-internet-lokal-diperkirakantumbuh-15, didownload tanggal 10 November 2011
Asas adalah dasar, landasan, cita-cita atau sesuatu yang menjadi tumpuan berpikir atau berpendapat. ${ }^{3}$ Asasasas hukum perdata adalah cita-cita atau falsafah yang mendasari ketentuan dalam hukum perdata itu dibuat.

Pengertian merek menurut Pasal 1 Angka 1 UU Merek adalah termasuk pula nama. Hak atas merek adalah hak eksklusif yang diberikan oleh Negara kepada pemilik Merek yang terdaftar dalam Daftar Umum Merek untuk jangka waktu tertentu dengan menggunakan sendiri Merek tersebut atau memberikan izin kepada pihak lain untuk menggunakannya. ${ }^{4}$ Hal ini berarti bahwa penggunaan merek yang dilindungi hanya dapat dilakukan oleh pemilik merek sebagai pelaksanaan hak eksklusifnya. Pihak lain yang tanpa persetujuan pemilik merek dilarang untuk menggunakan merek tersebut dalam kegiatan perdagangan produk berupa barang atau jasa.

Selanjutnya dalam Pasal 4 UU Merek dinyatakan bahwa, "Merek tidak dapat didaftar atas dasar Permohonan yang diajukan oleh Pemohon yang beritikad tidak baik".

Berdasarkan pasal ini, pemohon yang beritikad baik adalah pemohon yang mendaftarkan mereknya secara layak dan jujur tanpa ada niat untuk meniru atau menjiplak ketenaran merek pihak lain demi kepentingan usahanya yang berakibat kerugian pada pihak lain atau menyesatkan konsumen.

Pasal Pasal 6 ayat (3) huruf a menyatakan bahwa, "Permohonan juga harus ditolak oleh Direktorat Jenderal apabila Merek tersebut merupakan atau menyerupai nama orang terkenal, foto, atau nama badan hukum yang dimiliki orang lain, kecuali atas persetujuan tertulis dari yang berhak". Persamaan menurut Pasal 6 ini adalah sesuai dengan doktrin identical atau nearly resembles. Persamaan pada pokoknya dianggap sudah terwujud apabila merek tersebut mempunyai kemiripan (identical) atau hampir mirip (nearly resembles) dengan merek orang lain. ${ }^{5}$

Sebagai wujud penegakan hukum merek, dalam UU Merek diberikan hak kepada pemilik merek tidak terdaftar untuk melakukan gugatan pembatalan merek sebagaimana diatur dalam Pasal 68 ayat (2), yang menyatakan bahwa, "Pemilik Merek yang tidak terdaftar dapat mengajukan gugatan sebagaimana dimaksud pada ayat (1) setelahmengajukan Permohonan kepada Direktorat Jenderal."

Tindakan hukum berupa gugatan ganti rugi perdata juga diberikan sebagai bentuk perlindungan hukum bagi pemilik merek yang merasa hak atas mereknya dilanggar. Pasal 76 ayat (1) huruf a menyatakan bahwa, "Pemilik Merek terdaftar dapat mengajukan gugatan terhadap pihak lain yang secara tanpa hak menggunakan Merek yang mempunyai persamaan pada pokoknya

3. Departemen Pendidikan Nasional, Kamus Besar Bahasa Indonesia, Balai Pustaka, Jakarta, hlm. 70.

4. Pasal 3 UU Merek

5. M. Yahya Harahap, Tinjauan Merek Secara Umum dan Hukum Merek Di Indonesia Berdasarkan Undang-Undang No. 19 Tahun 1992, Citra Aditya Bakti, Bandung, 1996, hlm. 417-418. Lih juga : Rachmadi Usman, op.cit., hlm. 329. 
atau keseluruhannya untuk barang atau jasa yang sejenis berupagugatan ganti rugi”. Ketentuan ini merupakan dasar yuridis dari pemegang hak merek untuk mengajukan gugatan secara perdata atau gugatan ganti kerugian terhadap pihak yang melakukan pelanggaran hak merek. Suatu perbuatan dapat dikatakan sebagai pelanggaran hak merek apabila perbuatan tersebut melanggar hak khusus dari pemilik hak merek. Pemilik hak atas merek dan / atau penerima lisensi merek dapat mengajukan gugatan perdatanya kepada Pengadilan Niaga. ${ }^{6}$

Masalah yang hendak ditelaah adalah sebagai berikut:

1. Prinsip hukum apakah yang dapat diterapkan dalam melindungi orang terkenal dari cybersquatting yang menggunakan namanya sebagai nama domain tanpa izin?

2. Bagaimanakah konsep pengaturan merek yang lebih memadai dalam melindungi orang terkenal dari cybersquatting di era TIK di Indonesia?

\section{METODE}

Metode pendekatan yang dipergunakan dalam penelitian ini adalah yuridis normatif, yaitu penelitian hukum yang dilakukan dengan menelusuri, mengkaji, dan meneliti data sekunder (kepustakaan) yang berkaitan dengan materi penelitian. Data sekunder yang diperoleh dari bahan hukum primer yaitu berbagai peraturan perundang-undangan dan kebijakan yang berkaitan dengan materi penelitian, antara lain adalah: UUD 1945 beserta amandemennya, KUHPerdata, Undang-undang Nomor 15 Tahun 2001 Tentang Merek, Undang-undang Nomor 11 Tahun 2008 Tentang Informasi dan Transaksi Elektronik, Trademark Cyberpiracy Prevention Act 1999 of USA, Uniform Domain Name Dispute Resolution Policy (UDRP).

Bahan dianalisis dengan menggunakan metodemetode penafsiran hukum seperti penafsiran historis, penafsiran sistematis (logis), penafsiran sosiologis, dan penafsiran futuristis. ${ }^{7}$ Metode penafsiran historis dipergunakan untuk mengetahui latar belakang dan sejarah pembentukan peraturan perundang-undangan dan kebijakan dalam hal pemilikan dan penggunaan nama orang terkenal sebagai nama domain. Penafsiran sistematis digunakan mengingat banyaknya peraturan dan kebijakan yang mengatur pemilikan merek, penggunaan dan pemanfaatan nama orang terkenal sebagai nama domain. Metode penafsiran sosiologis diperlukan mengingat penerapan prinsip-prinsip hukum perdata dan merek serta hukum informasi dan transaksi elektronik dalam perlindungan hukum terhadap penggunaan nama orang terkenal sebagai nama domain, sehingga diperlukan pemahaman yang baik, mengenai nilai-nilai keadilan, demokrasi, perlindungan dan penegakkan hukum dalam

\footnotetext{
6. Pasal 76 ayat (2) dan Pasal 77 UU Merek.

Sudikno Mertokusumo, Penemuan Hukum: Sebuah Pengantar, Liberty, edisi pertama, Yogyakarta, 1996, hlm. 57-61.
}

arti yang sebenar-benarnya di masyarakat. Data sekunder sebagai bahan perbandingan dipergunakan pula, yaitu Trademark Cyberpiracy Prevention Act 1999 of USA dan Uniform Domain Name Dispute Resolution Policy (UDRP) serta literatur-literatur, hasil-hasil penelitian, hasil-hasil seminar dan lokakarya, dianalisis dengan menggunakan pendekatan abstrak-teoritis pula sebagai dasar analisisnya.

\section{HASIL DAN PEMBAHASAN}

\section{Prinsip-Prinsip Hukum Dalam Perlindungan Orang Terkenal dari Cybersquatting di Indonesia}

Prinsip-prinsip hukum kebendaan harus pula ditelaah mengingat nama orang terkenal yang semula termasuk dalam hak-hak perorangan, telah berkembang menjadi hak kebendaan dengan praktik penggunaan nama orang terkenal tersebut sebagai nama domain internet. Hal ini menyebabkan penggunaan tersebut mencakup pula aspek hukum bisnis, karena dalam perkembangannya nama orang terkenal tersebut telah menjelma menjadi asset bisnis dalam perdagangan secara elektronik (Electronic commerce).

Asas nemo-plus, seseorang tidak memperalihkan atau memperoleh hak lebih daripada yang ia miliki

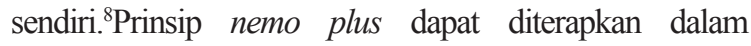
perlindungan nama orang terkenal dari cybersquatting, mengingat bahwa cybersquatter memang tidak memiliki hak apapun terhadap nama orang terkenal sehingga cybersquatter tidak memiliki kewenangan untuk memperalihkan nama orang terkenal sebagai nama domain. Cybersquatter hanya memiliki hak menggunakan namanya sendiri, dan tidak memiliki hak terhadap nama orang terkenal. Prinsip nemo plusini sebenarnya telah tercantum dalam Pasal 4 huruf a angka (ii) UDRP sebagai salah satu alas an untuk melakukan gugatan terhadap cybersquatter, yaitu syarat kedua berupa "hak atau kepentingan yang sah" (rights or legitimate interest). Pihak lain hanya dapat menggunakan nama orang terkenal sebagai nama domain apabila telah memperoleh ijin dari orang terkenal tersebut berdasarkan perjanjian.

Dalam kasus juliarobert.com, yang merupakan nama domain yang mengandung nama orang terkenal dan bukan merupakan merek terdaftar, fakta bahwa tergugat juga telah melelang nama domain ini di eBay telah membuktikan unsur itikad buruk sebagaimana dimaksud Pasal 4 huruf a (iii) dan Pasal 4 huruf (b) (i) UDRP.Hal-hal inilah yang kemudian menjadi salah satu alasan bagi panel WIPO untuk memenangkan gugatan Julia Robert terhadap Russel Boyd. ${ }^{9}$

Asas droit de suit, hak kebendaan (seperti hak milik) yang dimiliki oleh seseorang akan mengikuti kemanapun benda itu berada. Hak milik dikenal dengan

\footnotetext{
3. H.A. Volmar, Pengantar Studi Hukum Perdata,Pengantar Studi Hukum Perdata, Jilid 1,diterjemahkan oleh I.S. Adiwinata, Rajawali, Jakarta, 1983., hlm. 232.

9. WIPO Case No. D2000-0210 (29 May 2000)
} 
pengertian merupakan hak yang terkuat dan terpenuh, hak yang dimiliki seseorang ini akan melekat pada bendanya dimanapun benda itu berada. ${ }^{10}$ Pengejawantahan prinsip droit de suitdalam hal ini dilakukan dengan pemahaman bahwa nama orang terkenal yang semula merupakan hak perorangan menjadi hak kebendaan dengan bentuk nama domain, mengingat nama domain telah menjadi bentuk asset baru dalam dunia TIK. Dengan demikian, nama orang terkenal tetap memperoleh perlindungan hukum meskipun bentuk penggunaannya dilakukan di dunia maya yang sangat berbeda dengan dunia nyata. Hal ini karena berdasarkan asas droit de suitsuatu hak kebendaan mengikuti bendanya di mana saja dan dalam tangan siapapun benda itu berada. Dalam kajian cybersquatting ini, maka orang terkenal tetap memiliki hak eksklusif atas namanya dalam penggunaannya sebagai nama domain di dunia maya (internet).

Itikad baik dalam cybersquatting juga harus dinyatakan tidak ada apabila cybersquatting dilakukan terhadap obyek-obyek yang juga dilindungi untuk tidak dilakukan persamaan pada pokoknya atau persamaan keseluruhannya dalam Pasal 6 UU Merek, seperti nama dan/atau foto orang terkenal, nama badan hukum terdaftar, indikasi geografis yang sudah dikenal, atau nama Negara atau singkatan nama Negara, lambang atau emblem Negara atau lembaga internasional, serta tanda atau cap atau stempel resmi yang digunakan oleh Negara atau lembaga pemerintah. Ketentuan tentang larangan penggunaan nama atau foto orang terkenal dapat menelaah ketentuan serupa yang terdapat dalam Pasal 1129ACPA tentang perlindungan orang pribadi dari cybersquatting.

Pasal 1125 (d) (1) (B) Trademark Cyberpiracy Prevention Act 1999 juga mengatur tentang itikad buruk, selengkapnya dinyatakan bahwa dalam mempertimbangkan apakah seseorang memiliki itikad buruk atau tidak, pengadilan harus memperhatikan faktor-faktor antara lain ada tidaknya nama lengkap orang terkenal atau nama sebutan lain yang diketahui secara umum merupakan nama untuk orang terkenal tersebut.

Prinsip penggunaan dalam kegiatan perdagangan atau bisnis juga dapat diterapkan dalam perlindungan nama orang terkenal sebagai nama domain. Penerapan prinsip ini bertitik tolak pada adanya penggunaan nama orang terkenal dalam kegiatan bisnis atau perdagangan sehingga nama orang terkenal tersebut memiliki makna kedua sebagai suatu tanda pembeda dalam kegiatan perdagangan atau bisnis tersebut. Berdasarkan ketentuan passing off dalam hukum merek di Amerika dan Inggris, nama orang terkenal harus dapat dibedakan sebagai sumber/asal barang atau jasa tertentu. ${ }^{11}$

Berdasarkan prinsip penggunaan ini, maka pendaftaran dan penggunaan nama domain yang

\footnotetext{
10. Sri Soedewi Masjhoen Sofwan, Hukum Perdata Hukum Benda, Seksi Hukum Perdata Fakultas Hukum UGM, Yogyakarta, 1978, hlm. 103. 11. Lindsay, David, Lindsay David, International Domain Names Law, $I C A N N$ and the UDRP, Hart Publishing, Oxford and Portland, Oregon, 2007, hlm. 221.
}

mengandung nama orang terkenal harus dianggap telah terjadinya "penggunaan dalam kegiatan perdagangan atau bisnis" yang merupakan hak orang terkenal untuk mengeksploitasi namanya sendiri. Hal ini sejalan dengan ketentuan Pasal 1129 TCPA yang menyatakan bahwa, "Any person who registers a domain name that consists of the name of another living person, or a name substantially and confusingly similar thereto, without that person's consent, with the specific intent to profit from such name by selling the domain name for financial gain to that person or any third party, shall be liable in a civil action by such person."

\section{Konsep Pengaturan Merek dalam Melindungi Orang Terkenal dariCybersquatting di Era TIK di Indonesia}

Konsep pengaturan merek yang lebih memadai dalam menghadapi cybersquatting di era TIK berdasarkan teori Negara hukum yang demokratis adalah pengaturan merek yang memberikan jaminan perlindungan dan keadilan bagi orang terkenal yang namanya digunakan oleh para cybersquatter untuk melakukan cybersquatting, sekaligus pengaturan yang mampu mendorong tercapainya kesejahteraan masyarakat melalui peningkatan transaksi di internet dengan menggunakan nama domain.

Menurut David Lindsay, berdasarkan UDRP status hukum nama orang terkenal yang tidak didaftarkan sebagai merek adalah tergantung pada prinsip-prinsip hukum merek yang diterapkan oleh masing-masing Negara di dunia. Dengan demikian, tiap Negara memiliki kewenangan untuk mengatur dan menentukan bagaimana bentuk dan konsep perlindungan hukum terhadap nama orang terkenal dari cybersquatting. ${ }^{12}$

Indonesia telah memiliki UU ITE yang dalam Pasal 23 jelas telah mengkualifikasikan cybersquatting sebagai perbuatan melawan hukum yang dapat dimintakan pertanggungjawaban hukum perdata dan hokum administrasi. Perlindungan dimaksud secara yuridis materil telah cukup memadai, namun secara yurids formil masih meninggalkan masalah hukum khususnya dalam hal hukum acara penyelesaian sengketa nama domain secara perdata. Hal ini mengingat bahwa ketentuan Pasal 39 ayat (1) bukanlah ketentuan yang lengkap, melainkan hanya kaidah penunjuk berlakunya peraturan perundangundangan tentang hukum acara yang akan diterapkan dalam kasus cybersquatting.

Dalam hukum yang sat ini berlaku, yang mengatur tentang penggunaan nama orang terkenal adalah UU Merek, dengan demikian, khusus bagi nama orang terkenal yang juga telah didaftarkan sebagai merek dapat menggunakan ketentuan UU ini dengan melakukan penafsiran terhadap beberapa ketentuan pasalnya.

Penyusunan UU Merek yang lebih memadai dalam memberikan perlindungan terhadap nama orang terkenal dari cybersquatting, perlu dilakukan dengan

12 Ibid. 
melakukan studi perbandingan hukum Negara lain, yang mencakup regulasi dan kasus-kasusnya. Michael Bogdan menyatakan bahwa evaluasi komparatif terhadap berbagai solusi yang berbeda-beda di berbagai Negara terkait isu yang sama atau serupa, akan sangat bermanfaat untuk pembuatan draft legislasi atau pekerjaan de lege ferenda yang lainnya. ${ }^{13}$

Undang-Undang Nomor 15 Tahun 2001 tentang Merek (selanjutnya ditulis UU Merek) jelas belum mengatur cybersquatting sebagai suatu bentuk pelanggaran merek, karena pada saat UU Merek ini dibuat, belum mengantisipasi perkembangan TIK yang menyebabkan lahirnya bentuk baru pemanfaatan merek sebagai nama domain. Dengan kata lain, UU Merek belum sejalan dengan perkembangan masyarakat yang telah memasuki bentuk masyarakat informasi (information society).

Pengkualifikasian cybersquatting sebagai suatu perbuatan melawan hukum di Indonesia, sebaiknya dilakukan secara jelas dan tegas dalam rumusan pasal sebagai suatu pelanggaran merek yang ditetapkan dalam perubahan UU Merek. Hal tersebut dapat diwujudkan dengan adanya pengaturan merek yang mencakup halhal sebagai berikut: pertama, menetapkan ruang lingkup hak ekslusif merek adalah juga mencakup pendaftaran dan penggunaan merek (termasuk nama orang terkenal) sebagai nama domain di internet. Hal ini dapat mempertegas pengaturan hak atas merek sebagaimana saat ini diatur dalam Pasal 3 Undang-Undang Nomor 15 Tahun 2001 tentang Merek (UU Merek).

Kedua, melarang penggunaan nama orang terkenal sebagai nama domain oleh pihak lain secara tanpa hak dan dengan itikad buruk. Hal ini dapat mempertegas pengaturan tentang itikad buruk sebagaimana saat ini diatur dalam Pasal 4 UU Merek. Terkait hal ini, perlu dibuat ayat baru dalam Pasal 4 yang khusus mengatur bahwa nama orang terkenal tidak dapat didaftarkan dan digunakan sebagai nama domain dengan itikad buruk. Itikad buruk dalam kajian perbandingan dengan Negara lain, dapat dilihat dalam pengaturan Pasal 1125 (d) (1) (A) ACPA, yang unsurnya dapat juga mengambil contoh pengaturan dalam 1125 (d) (1) (B) ACPA yang telah merinci bentukbentuk itikad buruk dalam cybersquatting.

Itikad buruk dalam cybersquatting juga harus dinyatakan ada apabila cybersquatting dilakukan terhadap obyek-obyek yang juga dilindungi, seperti: nama dan/atau foto orang terkenal, nama badan hukum terdaftar, indikasi geografis yang sudah dikenal, atau nama Negara atau singkatan nama Negara, lambing atau emblem Negara atau lembaga internasional, serta tanda atau cap atau stempel resmi yang digunakan oleh Negara atau lembaga pemerintah. termasuk nama orang terkenal). Itikad buruk juga harus dicegah dengan caratidak dilakukan persamaan pada pokoknya atau persamaan keseluruhannya dengan obyek-obyek perlindungan yang ada dalam Pasal 6 UU Merek.

13. Michael Bogdan, Pengantar Perbandingan Sistem Hukum, terjemahan Derta Srie Widiowatie, Bandung: Nusa Media, 2010, hlm. 9.
Ketentuan tentang larangan penggunaan nama atau foto orang terkenal dapat menelaah ketentuan serupa yang terdapat dalam Pasal 1129 ACPA tentang perlindungan orang pribadi dari cybersquatting, serta putusan Panel WIPO dalam kasus "Madonna.com" yang menyatakan bahwa Daniel Parisi selaku tergugat telah melanggar merek "Madonna" yang didaftarkan oleh Madonna Ciccone, serta memerintahkan pemindahan koneksi nama domain tersebut.

Ketiga, memberikan hak kepada orang terkenal untuk mengajukan gugatan ganti rugi perdata terhadap cybersquatter. Ketentuan ini digunakan untuk melengkapi ketentuan Pasal 76 UU Merek yang mengatur tentang gugatan ganti rugi perdata atas pelanggaran merek. Dengan demikian, perlu diatur terlebih dahulu bentuk pelanggarannya, yaitu bahwa penggunaan nama orang terkenal sebagai nama domain oleh pihak lain tanpa ijin merupakan pelanggaran. Ketentuan ini dapat dirumuskan dalam ayat (2) baru dari Pasal 76, sedangkan ayat (2) lama terkait kewenangan Pengadilan Niaga dalam penyelesaian gugatan ganti rugi perdata dijadikan sebagai ayat (3) baru. Dalam perumusan ayat (2) baru tersebut, perlu ditegaskan bahwa cybersquatting tidak mensyaratkan adanya penggunaan untuk barang atau jasa yang sejenis atau tidak perlu dikaitkan dengan penggunaan untuk barang atau jasa. Hal ini mengingat bahwa nama domain memiliki sifat penggunaan yang berbeda dengan merek secara konvensional. Ketentuan serupa juga terdapat dalam Pasal 1129 (1) (A) ACPA tentang Cyberpiracy Protection for Individuls.

Keempat, memberikan kewenangan kepada pengadilan niaga untuk memeriksa dan mengadili perkara cybersquatting. Ketentuan ini untuk menegakkan hak eksklusif merek dan nama orang terkenal dari pelanggarannya berupa cybersquatting. Pasal 76 ayat (2) UU Merek yang mengatur kewenangan Pengadilan Niaga ini perlu merujuk kepada ketentuan yang memberikan hak kepada orang terkenal untuk mengajukan gugatan ganti rugi perdata terhadap cybersquatter. Kajian perbandingan mengenai hal ini dapat dilakukan berdasarkan ketentuan Pasal 1125 (d) (2) (A) yang memberikan kesempatan kepada pemilik merek untuk mengajukan gugatan "in rem" di pengadilan yang wilayah hukumnya mencakup tempat kedudukan registrar atau otoritas lainnya yang terkait dengan pendaftaran nama domain. Di Cina, pengadilan yang wilayah hukumnya meliputi tempat yang dapat mengakses website yang merupakan nama domain cybersquatting, memiliki kewenangan mengadili sehingga tidak ada pengadilan di Cina yang tidak memiliki kewenangan in rem mengingat nama domain dapat diakses dari mana pun di wilayah Cina.

Praktik cybersquatting dan/atau typosquatting juga harus secara tegas dinyatakan sebagai penggunaan nama orang terkenal dalam kegiatan bisnis, sehingga kualifikasi keduanya sebagai pelanggaran menjadi semakin tepat. Penggunaan nama domain untuk iklan 
atau konten lain atau bahkan hanya sekedar pendaftaran nama orang terkenal sebagai nama domain saja harus dikualifikasikan sebagai kegiatan bisnis. Khusus bagi pendaftaran nama orang terkenal yang hanya untuk "diparkirkan" (warehousing), harus diartikan sebagai penggunaan nama orang terkenal dengan itikad buruk. Hal ini dapat digunakan untuk mempertegas pengertian merek sebagaimana saat ini terdapat dalam Pasal 1 angka 1 UU Merek, serta memberikan tambahan penjelasan dari kata "menggunakan" sebagaimana terdapat dalam ketentuan Pasal 3 UU Merek.

\section{SIMPULAN}

Prinsip nemo plus, droit de suit, itikad baik, prinsip persamaan, dan prinsip penggunaan dalam kegiatan perdagangan atau bisnis dapat digunakan dalam melindungi orang terkenal dari penggunaan namanya sebagai nama domain. Pendekatan hukum pidana tidak perlu dilakukan, mengingat cybersquatting terhadap nama orang terkenal adalah perbuatan hukum perdatayang akan lebih proporsional jika dilakukan pendekatan hukum perdata. Hal ini sejalan dengan prinsip ultimum remidium. Prinsip-prinsip hukum pidana baru dapat dilakukan jika cybersquatting terhadap nama orang terkenal juga diikuti dengan perbuatan pidana terkait muatan atau konten dalam nama domain tersebut. Konsep pengaturan merek yang lebih memadai dalam melindungi orang terkenal dari penggunaan namanya sebagai nama domain adalah konsep pengaturan yang mengandung hal-hal sebagai berikut; a. Penetapkan ruang lingkup hak ekslusif merek adalah juga mencakup pendaftaran dan penggunaan nama orang terkenal sebagai nama domain di internet, b. Pelarangan penggunaan nama orang terkenal sebagai nama domain oleh pihak lain secara tanpa hak dan dengan itikad buruk, c. pemberian hak kepada orang terkenal untuk mengajukan gugatan ganti rugi perdata terhadap cybersquatter, d. Pemberian kewenangan kepada pengadilan niaga untuk memeriksa dan mengadili perkara cybersquatting;

\section{DAFTAR PUSTAKA}

Aamna, "Cybersquatting: Indian and American Law", http://jurisonline.in/?p=2644, 21

David Baumer, J.C. Poindexter, Cyberlaw and E-Commerce: Security, Risk Management, and Control, New York: McGraw-Hill, 2002

Departemen Pendidikan Nasional, Kamus Besar Bahasa Indonesia, Balai Pustaka, Jakarta

http://www.300ribu.com/domain-internet-lokaldiperkirakan-tumbuh-15

Lindsay, David, International Domain Names Law, ICANN and the UDRP, Hart Publishing, Oxford and Portland, Oregon, 2007

M. Yahya Harahap, Tinjauan Merek Secara Umum dan Hukum Merek Di Indonesia Berdasarkan Undang-Undang No. 19 Tahun 1992, Citra Aditya Bakti, Bandung, 1996

Michael Bogdan, Pengantar Perbandingan Sistem Hukum, terjemahan Derta Srie Widiowatie, Bandung: Nusa Media, 2010

Rachmadi Usman, Mediasi di Pengadilan, Sinar Grafika, Jakarta

Sri Soedewi Masjhoen Sofwan, Hukum Perdata Hukum Benda, Seksi Hukum Perdata Fakultas Hukum UGM, Yogyakarta, 1978

Sudikno Mertokusumo, Penemuan Hukum: Sebuah Pengantar, Liberty, edisi pertama, Yogyakarta, 1996

Volmar, H.F.A., Pengantar Studi Hukum Perdata, Pengantar Studi Hukum Perdata, Jilid 1, diterjemahkan oleh I.S. Adiwinata, Rajawali, Jakarta, 1983 WIPO Case No. D2000-0210 (29 May 2000) 